\title{
Bartlomiej Ślemp
}

\section{Wybrane formalnoprawne i praktyczne aspekty kompetencji klubów parlamentarnych}

Autor przybliża formalnoprawne oraz częściowo praktyczne aspekty klubów
parlamentarnych związane $\mathrm{z}$ ich kompetencjami, wynikającymi z przepisów
regulaminowych obu izb polskiego parlamentu. Artykuł przedstawia głównie regulaminy
Sejmu i Senatu. W celu dokonania stosownej klasyfikacji uprawnień klubów
parlamentarnych Autor odnosi się również do innych aktów wewnętrznych i źródeł prawa
powszechnie obowiązującego, w tym regulacji niemieckiego Bundestagu. Wykorzystując
orzecznictwo Trybunału Konstytucyjnego oraz wyrażone poglądy doktryny ukazuje ważną
rolę tego rodzaju zrzeszenia parlamentarzystów w funkcjonowaniu Sejmu i Senatu RP.
Wskazuje także na zjawisko dyscypliny klubowej, jako uprawnienie klubu parlamentarnego,
odnosząc się do praktycznych przykładów i popierając je szeroką analizą uregulowań
wewnątrzklubowych.

\section{Uwagi wprowadzające}

Celem opracowania jest przedstawienie prawnych i częściowo praktycznych aspektów klubu parlamentarnego w zakresie jego uprawnień, przysługujących mu w toku prac Sejmu i Senatu RP. Zostaną one wskazane na tle aktów normatywnych, jak i materii regulaminowej obu izb oraz wybranych wewnętrznych regulacji zrzeszeń wraz z postulatami de lege ferenda opartymi na regulacjach parlamentu Republiki Federalnej Niemiec. Jest to kontynuacja poprzedniego artykułu (opublikowanego w numerze 2017/4 Młodego Jurysty - podkr. Redakcja) dotyczącego rysu historycznego, idei tworzenia oraz podstaw działalności tego typu zrzeszenia parlamentarzystów ${ }^{1}$.

$\mathrm{Na}$ wstępie należy podkreślić, że tworzenie zrzeszeń, w tym klubów parlamentarnych, nie jest tylko wyrazem uporządkowania frakcji politycznych w parlamencie, ale także realizacją jego ustrojowej funkcji, jaką jest stanowienie prawa zgodnie z wolą większości parlamentarnej.

\footnotetext{
${ }^{1}$ Por. B. Ślemp, Status ustrojowy klubów parlamentarnych, „Młody Jurysta” 2017, nr 4.
} 
W szczególności liczne uprawnienia ${ }^{2}$ przyznają im unormowania regulaminu Sejmu, w mniejszym stopniu regulaminu Senatu³ . Dzięki temu możliwe jest sprawne procedowanie obu izb i dokonanie istotnych z punktu widzenia procesu legislacyjnego czynności zgodnie z obowiązującym prawem i założeniami poszczególnych grup politycznych.

Nie bez znaczenia dla działalności posłów i senatorów w ramach ich przynależności do zrzeszeń parlamentarnych pozostaje brzmienie art. 106 Konstytucji Rzeczypospolitej Polskiej z 2.4.1997 r. ${ }^{4}$, który odsyła do ustawy z 9.5.1996 r. o wykonywaniu mandatu posła i senatora ${ }^{5}$. Regulacja art. 17 ustawy podkreśla doniosłą rolę klubów, kół i zespołów poselskich, senatorskich oraz parlamentarnych w funkcjonowaniu obu izb ${ }^{6}$. W praktyce rola ta szczególnie uwidacznia się w Sejmie dzięki działalności klubów parlamentarnych (zazwyczaj najliczniejszych, dysponujących odpowiednim kapitałem politycznym oraz głosami w izbie $)^{7}$. $\mathrm{Na}$ poczet dalszych rozważań uważam, że pojęcie „klub poselski” (per analogiam „klub senacki”) i „klub parlamentarny” należy utożsamić. W wielu unormowaniach regulaminowych dotyczących uprawnień tychże zrzeszeń uchwałodawca nie czyni takiego rozróżnienia lub wprost wskazuje na kompetencje klubu parlamentarnego i poselskiego w zakresie danej kwestii, jednocześnie nie różnicując ich pozycji względem siebie, gdyż naruszałoby to ugruntowaną praktykę parlamentarną i zasadę pluralizmu politycznego. Mimo zamkniętego katalogu organów Sejmu (art. 9 RSEJ), podtrzymuję stanowisko, iż owe zrzeszenia, z uwagi na ich funkcję oraz odpowiednie organizacyjne wyodrębnienie mogą zostać uznane za quasiorgany tejże izby. Kwestie te zostały szerzej omówione w poprzednim artykule ${ }^{8}$.

\section{Uprawnienia klubów parlamentarnych}

W mojej opinii uprawnienia klubów parlamentarnych w ścisłym znaczeniu można podzielić na formalne i nieformalne. Są one związane z funkcjonowaniem zrzeszeń

\footnotetext{
${ }^{2}$ Uchwała Sejmu Rzeczypospolitej Polskiej z 30.7.1992 r. Regulamin Sejmu Rzeczypospolitej Polskiej, tekst jedn. M.P., poz. 32 ze zm., dalej jako RSEJ.

${ }^{3}$ Uchwała Senatu Rzeczypospolitej Polskiej z 23.11.1990 r. Regulamin Senatu Rzeczypospolitej Polskiej, tekst jedn. M.P. z 2015 r., poz. 805 ze zm, dalej jako RSEN.

${ }^{4}$ Dz. U. Nr 78, poz. 483 ze zm., dalej także jako: Konstytucja RP, Konstytucja.

${ }^{5}$ Tekst jedn. Dz. U. z 2016 r., poz. 1510 ze zm., dalej jako UWMPS.

${ }^{6}$ Przede wszystkim ze względu na to, że ustrojodawca zdecydował się kwestie dotyczące zrzeszeń częściowo uregulować na poziomie ustawowym. Ponadto por. K. Grajewski, [w:] K. Grajewski, J. Stelina, P. J. Uziębło, Komentarz do ustawy o wykonywaniu mandatu posła i senatora., Warszawa 2014, komentarz do art. 17, LEX. („Artykuł 17 jest przepisem ustawowym stwarzającym partiom politycznym możliwość realizacji funkcji uczestnictwa w sprawowaniu władzy państwowej przy wykorzystaniu mechanizmów parlamentarnych.”).

${ }^{7}$ Por. konkluzje nt. wpływu klubów i kół parlamentarnych na prace Sejmu i jego organów (M.A. Kamiński, Status prawny klubów i kót parlamentarnych w Sejmie RP, Toruń 2015, s. 110).

8 B. Ślemp, Status ustrojowy klubów parlamentarnych, „Młody Jurysta” 2017, nr 4.
} 
i procedowaniem w parlamencie, czyli de facto $\mathrm{z}$ wykonywaniem mandatu posła czy senatora $\mathrm{w}$ procesie stanowienia prawa.

Wśród uprawnień formalnych rozróżniam: uprawnienia bezpośrednie, które rozumiem jako uprawnienia przysługujące expressis verbis klubowi (jako jednemu ciału) oraz uprawnienia pośrednie przyznane określonej liczbie parlamentarzystów (np. 15 posłom), które dzięki temu jednocześnie mogą przysługiwać grupie posłów z tej samej frakcji, a co za tym idzie, również pośrednio klubowi. Warto zauważyć, że zarówno uprawnienia bezpośrednie, jak i pośrednie, nie muszą wynikać wprost z RSEJ i RSEN, a np. z Konstytucji czy wewnętrznie wiążących aktów wykonawczych wydawanych na podstawie ustaw ${ }^{9}$ ). W przypadku przepisu regulaminowego, który zakłada uprawnienia dla klubu i grupy posłów, można mówić o wzajemnym pokrywaniu się obu rodzajów kompetencji formalnych. Niektóre uprawnienia pośrednie nie będą przysługiwały wyodrębnionej grupie posłów klubu, czy nawet wszystkim jego członkom, jeśli minimalny próg ilościowy, wyrażony w danym przepisie będzie większy, niż liczba osób składających dany wniosek (choćby poparł go cały klub $)^{10}$. Czynności dokonywane na podstawie uprawnień bezpośrednich nie mogą być poparte przez posłów $\mathrm{z}$ innego klubu w ramach tego samego jednego wniosku. W takim wypadku kluby te mogą składać swoje odrębne wnioski, korzystając z uprawnień bezpośrednich. W związku z tym poparcie przez członka danego klubu inicjatywy in pleno innego klubu nie wywołuje wobec niej żadnych skutków prawnych ${ }^{11}$. Przywileje nieformalne nie znajdują odzwierciedlenia w przepisach prawa - ani w aktach powszechnie obowiązujących, ani w wewnętrznie wiążących. Mają często wymiar polityczny i w konsekwencji mogą prowadzić do skorzystania z uprawnień formalnych. Tytułem przykładu można wskazać, że kluby reprezentujące wiodące frakcje parlamentarne, a więc zazwyczaj cieszące się największym uznaniem wyborców (przynajmniej w momencie rozpoczęcia kadencji Sejmu i Senatu), mogą liczyć zdecydowanie na większą popularność w mediach (z uwagi na możliwość decydowania o sprawach rozpatrywanych w parlamencie ich zdanie jest bardziej „medialnie” pożądane). Ponadto liczebniejsze kluby (mające wpływ w parlamencie na przebieg jego prac) prowadzą nieformalne rozmowy polityczne w sposób bardziej efektywny, co umożliwia łatwiejsze budowanie wspólnej linii politycznej (lub powstawanie nowych

\footnotetext{
${ }^{9}$ Por. rozważania w pkt 3 dot. uchwał Prezydium Sejmu i Prezydium Senatu w przedmiocie zakwaterowania odpowiednio posłów i senatorów.

${ }^{10}$ Por. np. art. 172 ust. 2 RSEJ - wystąpienie z wnioskiem o tajność obrad przez co najmniej 30 posłów; art. 189 ust. 3 RSEJ - wystąpienie z pisemnym wnioskiem o reasumpcję głosowania przez co najmniej 30 posłów.

${ }^{11}$ Jedynie zmiana przynależności przez takiego parlamentarzystę i co za tym idzie członkostwo w zrzeszeniu, które skorzystało z tego uprawnienia bezpośredniego, pozwala na reprezentowanie (w znaczeniu politycznym) przez niego poglądu wyrażonego (w znaczeniu prawnym) in pleno przez klub.
} 
zrzeszeń poprzez połączenie dotychczas istniejących). Konsolidacja parlamentarzystów o podobnych poglądach ułatwia gromadzenie elektoratu. Takie zaś działania często skłaniają kluby do skorzystania np. z oczekiwanej przez wyborców inicjatywy ustawodawczej. Kompetencje te nie będą poddane dalszej analizie, gdyż stanowią pole badań głównie nauk politologicznych i socjologicznych.

Wyżej rozróżnione uprawnienia przysługują niekiedy tylko klubom bez równoległego przyznania ich kołom czy zespołom. Przyczyną takiego stanu rzeczy jest: (i) w przypadku uprawnień bezpośrednich - przyznanie ich nieraz tylko klubom działającym in pleno oraz (ii) określona w niektórych przepisach minimalna liczebność parlamentarzystów, którzy z danego uprawnienia pośredniego mogą skorzystać. Mogłoby się wydawać, że kluby, jako te najliczniejsze, są w pewien sposób „faworyzowane” przez uchwałodawcę ${ }^{12}$. Jednak sposób ukształtowania niektórych regulacji przewidujących kompetencje dla określonej ilościowo grupy posłów, służy nie tylko podkreślaniu roli klubów (korzystających z uprawnień pośrednich), ale i zabezpieczeniu prawa każdego deputowanego, w tym w szczególności nieprzynależącego do żadnego z klubów, do uczestniczenia w pełni w pracach parlamentu. Każdy z nich może złożyć swój podpis pod daną inicjatywą, jeśli przysługuje ona grupie posłów ${ }^{13}$.

Warto zaznaczyć, że część regulacji przewiduje zarówno kompetencję bezpośrednią, jak i pośrednią ${ }^{14}$.

Poza opisywanymi kompetencjami, które należy rozumieć ściśle, można wyróżnić kompetencje $\mathrm{w}$ szerokim znaczeniu. W tym przypadku $\mathrm{w}$ przedstawionej klasyfikacji należałoby ująć inne pozaparlamentarne funkcje zrzeszeń, niezwiązane z wykonywaniem mandatu przez parlamentarzystę $\mathrm{W}$ procesie stanowienia prawa. Innymi słowy, to uprawnienia wprost nie odnoszące się do pracy posła czy senatora w izbie (indywidualnie w ramach grupy posłów lub jako klub in pleno). Nie będą one w tym miejscu omawiane. Przykładem tych kompetencji jest art. 48 ust. 1 pkt 2 ustawy z 14.3.2003 r. o referendum ogólnokrajowym ${ }^{15}$, który stwierdza, że ,[p]odmiotami uprawnionymi do udziału w kampanii referendalnej w programach radiowych i telewizyjnych (...) są (...) klub poselski,

\footnotetext{
${ }^{12}$ Tak dzieje się np. w przypadku skorzystania z prawa inicjatywy ustawodawczej, którą posiada 15 posłów, co wyklucza wniosek posłów z wyłącznie jednego koła poselskiego (niepoparty przez innych parlamentarzystów).

${ }^{13} \mathrm{Z}$ jednej strony rozwiązanie to w praktyce preferuje kluby, które ze względu na swoją liczebność, $\mathrm{z}$ łatwością mogą zebrać wymaganą liczbę podpisów pod danym wnioskiem. $Z$ drugiej zaś, jest to stworzenie możliwości udziału w pracach parlamentu również posłów niezrzeszonych bądź niewystarczająco liczebnych zrzeszeń.

${ }^{14}$ Por. np. art. 173 ust. 3 - wniosek o uzupełnienie porządku dziennego może zgłosić klub, koło oraz grupa co najmniej 15 posłów.

${ }^{15}$ Tekst jedn. Dz. U. z 2015 r., poz. 318.
} 
klub senatorski oraz klub parlamentarny, które na rok przed dniem ogłoszenia uchwały lub postanowienia o zarządzeniu referendum zrzeszały odpowiednio posłów lub senatorów wybranych spośród kandydatów zgłoszonych przez komitet wyborczy wyborców, a posłowie lub senatorowie ci stanowili więcej niż połowę składu tych klubów”. Szerokie rozumienie tego pojęcia może obejmować też prawo klubu do organizowania wydarzeń o charakterze niepaństwowym, niezwiązanych ze spełnianiem przez niego funkcji ustrojowych ${ }^{16}$.

Powyższe rozważania odnoszące się głównie do praktyki sejmowej należy odpowiednio odnieść do procedowania Senatu. Uprawnienia formalne, wynikające przede wszystkim z regulaminu tejże izby, z uwagi na jej charakter (,izba refleksji, zadumy”) pozostają jednak W znaczącej dysproporcji do zakresu tego typu kompetencji, wynikającego z RSEJ. W izbie wyższej uchwałodawca zdecydował się na dużą indywidualizację uprawnień każdego z jej członków, co ma ułatwić merytoryczną dyskusję w toku senackich prac legislacyjnych. Uprawnienia pośrednie na gruncie RSEN w większości mają charakter techniczny i porządkowy w celu usprawnienia funkcjonowania izby.

\section{Bezpośrednie uprawnienia klubów parlamentarnych}

Regulamin Sejmu Rzeczypospolitej Polskiej określa relacje zachodzące między poszczególnymi organami Sejmu a quasi-organami Sejmu. To właśnie w tych przypadkach najczęściej mamy do czynienia z kompetencjami bezpośrednimi klubów parlamentarnych (per analogiam w Senacie).

Artykuły 14 i 15 tego aktu stwierdzają, że w skład Konwentu Seniorów, który ,zapewnia współdziałanie klubów w sprawach związanych z działalnością i tokiem prac Sejmu", wchodzą m. in. przewodniczący lub wiceprzewodniczący klubów poselskich, a także przedstawiciele porozumień $\mathrm{z}$ art. 8 ust. 5 RSEJ i klubów parlamentarnych, jeśli reprezentują co najmniej 15 posłów. Ponadto jego zwołanie może odbyć się na wniosek m. in. klubu w nim reprezentowanego (art. 16 ust. 2 RSEJ). Mimo nieznaczących uprawnień

\footnotetext{
16 „Nie ulega wątpliwości, że klub parlamentarny może być również organizatorem wydarzeń lub uroczystości o charakterze niepaństwowym (,prywatnym”), które wykraczają poza ramy prawne, określające rolę ustrojową partii lub ich frakcji parlamentarnych. Trudno jest uznać, że opisane powyżej uroczystości [chodziło o uroczystości upamiętniające katastrofę smoleńską - przyp. autor] mieszczą się w wypełnianej przez partie polityczne lub ich organizacje parlamentarne funkcji sprawowania władzy państwowej, którą szeroko scharakteryzowano w orzecznictwie Trybunału Konstytucyjnego", por. I. Galińska-Rączy, Opinia prawna w sprawie ujawniania w Rejestrze Korzyści zagranicznej wizyty sfinansowanej przez zapraszajacego odbytej przez posła jako członka zespołu parlamentarnego, „Zeszyty Prawnicze BAS”, Rok IX 4 (36) 2012, s.222, [cyt. za:] K. Grajewski, Opinia na temat art.28 ust. 2 ustawy o wykonywaniu mandatu posła i senatora w zwiazku z art. 3 ust. 3 pkt 3 ustawy o ubezpieczeniu społecznym z tytułu wypadków przy pracy i chorób zawodowych, niepubl.
} 
regulaminowych jest to główny organ polityczny Sejmu konsultujący to, czym będzie się zajmowała izba ${ }^{17}$. Jego prace wstępnie pozwalają nakreślić stanowiska poszczególnych frakcji parlamentarnych. Samo brzmienie art. 14 RSEJ wskazuje na kluby i ich wzajemne współdziałanie, co jeszcze bardziej podkreśla ich wiodącą rolę wśród innych zrzeszeń.

Pomimo minimalnego uwarunkowania ilościowego w liczbie 15 posłów dla obecności w Konwencie przedstawiciela klubu parlamentarnego, uważam, że jest to kompetencja bezpośrednia. Zgodnie $\mathrm{z}$ argumentacją przedstawioną $\mathrm{W}$ poprzednim artykule, dotyczącą kwestii minimalnej ilości członków - posłów i senatorów - mogących utworzyć klub parlamentarny (tak by w Sejmie przysługiwały mu kompetencje klubu poselskiego, o którym mowa w art. 8 ust. 2 RSEJ) uważam, że wynosi ona 15 posłów i 1 senator. W takim jednak przypadku klubowi parlamentarnemu nie przysługiwałyby w Senacie uprawnienia klubu senackiego; taka sytuacja miałaby miejsce dopiero po osiągnięciu progu z art. 21 ust. 2 RSEN - 7 senatorów. Należy zatem skonkludować, że regulacja z art 15 ust. 1 RSEJ, wskazująca na kluby parlamentarne liczące minimum 15 posłów, potwierdza bezpośredni charakter omawianej kompetencji ${ }^{18}$.

Warto zwrócić uwagę na sam skład Konwentu. W przypadku, gdy koło parlamentarne nie reprezentowało w dniu rozpoczęcia kadencji Sejmu osobnej listy wyborczej, zmuszone jest stworzyć porozumienie do wspólnej reprezentacji w tym organie $\mathrm{z}$ innymi zrzeszeniami, tak, by liczyło minimalnie 15 posłów ${ }^{19}$. Jeśli chodzi o klub parlamentarny, nawet powstały w trakcie kadencji, takich wymogów (reprezentacja wspólnej listy wyborczej) nie ma. Obecność jego przedstawiciela jest trafnym założeniem, gdyż przewodniczącym klubu mógłby być senator, który nie jest de iure członkiem izby niższej. Stąd reprezentowanie klubu przez posła - przedstawiciela - jest logiczne i poprawne ${ }^{20}$.

Podobne rozwiązanie zostało przyjęte w Senacie. Zgodnie z art. 16 ust. 2 RSEN Konwent Seniorów tworzą m. in. przedstawiciele klubów senackich oraz przedstawiciele porozumień, o których mowa w art. 21 ust. 5, a także klubów parlamentarnych, jeżeli skupiają co najmniej 7 senatorów. W tym wypadku wykładnia tej regulacji winna być tożsama

\footnotetext{
${ }^{17}$ Por. P. Chybalski, Opinia prawna w sprawie uprawnień postów niezrzeszonych - wedlug pytań szczegótowych, „Zeszyty Prawnicze BAS”, nr 1 (45) 2015, s. 188-189.

${ }^{18} \mathrm{Z}$ uwagi na fakt, że zgodnie z przedstawioną koncepcją, nigdy klubowi parlamentarnemu liczącemu mniej niż 15 posłów w Sejmie przy spełnieniu minimalnej liczebności w Senacie nie będą przysługiwać kompetencje klubu poselskiego w Sejmie.

${ }^{19}$ Por. B. Szepietowska, Status prawny klubu i koła parlamentarnego, [w:] Regulamin Sejmu w opiniach Biura Analiz Sejmowych, tom I, red. W. Odrowąż-Sypniewski, Warszawa 2010, s. 65-70. Autorka wyraża m. in. pogląd o reprezentacji w Konwencie Seniorów kół, które zostały utworzone w dniu rozpoczęcia kadencji i w trakcie, jednocześnie reprezentując oddzielną listę wyborczą.

${ }_{20}$ Tak też B. Szepietowska, Zasady na jakich opiera się reprezentacja klubu parlamentarnego $w$ Konwencie Seniorów w Sejmie [w:] Ibidem, s. 118.
} 
z przedstawioną na gruncie RSEJ. W skład Konwentu Seniorów powinni wchodzić przedstawiciele klubów parlamentarnych, ale tylko tych liczących co najmniej 7 senatorów. Praktyka ostatnich lat, w tym bieżącej IX kadencji, potwierdza tę tezę ${ }^{21}$.

Innym przykładem relacji organ Sejmu - quasi-organ Sejmu jest proces udzielenia posłowi urlopu od wykonywania swoich obowiązków. Uczestniczy w nim prezydium klubu, którego poseł jest członkiem. Parlamentarzysta zwraca się w tej sprawie do Marszałka Sejmu, $\mathrm{a}$ ten udziela go $\mathrm{w}$ porozumieniu $\mathrm{z}$ prezydium klubu (art. 7 ust. 10 RSEJ). Faktycznie jest to instytucja rzadko wykorzystywana, jednak nadaje władzom klubu uprawnienie do udzielenia zgody. Znaczenie klubu parlamentarnego podkreślone jest również w przypadku zwrócenia się Prezydium Sejmu o jego opinię, zazwyczaj formułowaną przez władze klubowe (prezydium, kolegium), podczas rozpatrywania przez nie odwołania od uchwały Komisji Regulaminowej i Spraw Poselskich w związku ze stwierdzeniem niewykonywania obowiązków poselskich (art. 132 ust. 2 RSEJ) oraz odwołania od uchwały Komisji Etyki Poselskiej w przypadku stwierdzenia naruszenia przez posła „Zasad etyki poselskiej” (art. 147 ust. 1 i 4 RSEJ). Co prawda jest to fakultatywna czynność sprowadzona wyłącznie do wyrażenia opinii, a więc niewiążącego Prezydium stanowiska klubu, do którego dany poseł należy. W praktyce jednak często może być wykorzystywana jako środek pomocniczy w celu próby obrony członka danej frakcji, przedstawienia kontrargumentów, ogólnego wsparcia, jednak dopóki owa opinia nie zostanie uwzględniona przez organ rozpatrujący odwołanie $\mathrm{w}$ postaci przychylnego jej rozstrzygnięcia, ma tylko charakter polityczny. Należy zgodzić się ze wskazanym przez Wojciecha Odrowąż-Sypniewskiego ratio legis tej regulacji ${ }^{22}$. Jednakże jej wymiar praktyczny, w mojej ocenie, sprowadza się do przedstawionego wyżej stanowiska. Podkreśla ono jednocześnie zaletę przynależności

\footnotetext{
${ }^{21}$ Zob. Noty o Senacie. Marszałek i wicemarszatkowie Senatu, Prezydium Senatu, Konwent Seniorów, red. Biuro Komunikacji Społecznej Kancelarii Senatu, Warszawa 2016, s. 2.

${ }^{22}$ Zob. W. Odrowąż-Sypniewski, Opinia prawna na temat wyktadni skutków prawnych uchylenia przez Prezydium Sejmu uchwaty Komisji Etyki Poselskiej na podstawie art. 147 ust. 1 w zwiazku z art. 145 ust. 4 regulaminu Sejmu, „Zeszyty Prawnicze BAS”, nr 2 (34) 2012, s. 78-79. „Klub w praktyce nie dysponuje żadną wiedzą na temat postępowania prowadzonego przez komisję, a tym bardziej nie jest powołany do oceny jego prawidłowości. Zasięganie opinii zrzeszenia parlamentarnego ma sens tylko wówczas, jeśli uznać, że opinia taka powinna dotyczyć zasadności nałożenia kary w konkretnych okolicznościach sprawy. Analizowana procedura konsultacyjna wiąże się z przekonaniem twórców regulaminu, że środowisko polityczne, w którym funkcjonuje ukarany przez komisję, poseł z natury rzeczy ma najszerszą wiedzę na temat jego zachowań, a tym samym może ocenić ciężar rozpatrywanego deliktu. Macierzysty klub dysponuje również środkami perswazji charakterystycznymi dla zrzeszeń parlamentarnych, które mogą być wystarczające dla zdyscyplinowania niesubordynowanego posła. Innymi słowy, omawiana procedura opiera się na założeniu zbieżnym z przekonaniem, że Prezydium Sejmu, rozpatrując odwołanie, orzeka o istocie sprawy. Skoro bowiem stanowisko klubu dotyczyć powinno oceny zasadności nałożenia kary, to tym samym cała procedura, w której taka opinia jest wykorzystywana, służy dokonaniu takiej oceny".
} 
do klubu parlamentarnego, który ma pomocniczo ocenić ciężar czynu poselskiego niezgodnego z regulaminem. Przepisy te mają zastosowanie do kół poselskich.

W trakcie trzech czytań projektu ustawy w Sejmie również klubom przysługują pewne uprawnienia. Już podczas pierwszego czytania odbywającego się na posiedzeniu Sejmu zgodnie z art. 39 ust. 2 RSEJ można wnieść wniosek o odrzucenie projektu w całości. Regulamin nie precyzuje zakresu podmiotowego, tak więc wydaje się, że może zrobić to każdy poseł w imieniu klubu, którego jest członkiem (stosownie umocowany przez klub do występowania $\mathrm{w}$ jego imieniu ${ }^{23}$. Prawo wnoszenia poprawek w czasie drugiego czytania projektu ustawy przysługuje $\mathrm{m}$. in. przewodniczącemu lub upoważnionemu przez niego wiceprzewodniczącemu w imieniu klubu (art. 45 ust. 1 RSEJ). Przy złożeniu wniosku o odrzucenie projektu w całości (art. 45 ust. 2 RSEJ) stosuje się odpowiednio ust. 1. Kompetencje te są więc przykładem uprawnień bezpośrednich.

Szereg przepisów regulaminowych, w przypadku tworzenia określonych komisji, nakazuje odzwierciedlać odpowiednią proporcję ich członków w stosunku do wskazanych zrzeszeń. Tak dzieje się podczas rozpatrywania projektu ustawy o zmianie Konstytucji i powołaniu w tym celu Komisji Nadzwyczajnej (art. 86b ust. 2 RSEJ), której skład ma odpowiadać reprezentacji w Sejmie klubów i kół poselskich. Skład Komisji do Spraw Unii Europejskiej (art. 148a ust. 2 RSEJ) „,powinien odzwierciedlać proporcjonalnie reprezentację w Sejmie klubów i porozumień liczących co najmniej 15 posłów”. Ponownie dostrzec można uprzywilejowaną pozycję klubu parlamentarnego w stosunku do zmieniających się pozostałych podmiotów (porozumienie, koło). W przypadku zgłaszania kandydatów na członków komisji śledczej, mogą tego dokonywać przewodniczący klubów i kół, którzy wchodzą w skład Konwentu Seniorów (art. 136c ust. 2 RSEJ). To Prezydium Sejmu określa liczbę miejsc przypadającą danemu klubowi czy kołu. W związku z powyższym tylko te dwa zrzeszenia parlamentarne mogą wskazywać swoich członków na kandydatów do składu tego rodzaju komisji. Jeśli chodzi o obsadzanie miejsc w Komisji do Spraw Służb Specjalnych (art. 137 ust. 3 RSEJ) sytuacja jest podobna, jednak zachodzą pewne różnice: kandydatów zgłaszają tylko przewodniczący klubów poselskich lub grupy co najmniej 35 posłów. Wykluczone zostało uprawnienie przewodniczących kół parlamentarnych z utrzymaniem go dla przewodniczących klubów. Odnośnie do sformułowania „klubów poselskich”, nie ma

\footnotetext{
${ }^{23}$ Wydaje się, że dozwoloną interpretacją byłaby także możliwość zgłoszenia wniosku przez posła w imieniu własnym (co zgodne jest $\mathrm{z}$ istotą zasady wolnego mandatu) lub przez grupę posłów, w tym z tego samego zrzeszenia. W związku z tym należałoby mówić tutaj o regulacji zawierającej kompetencję bezpośrednią i pośrednią jednocześnie.
} 
wątpliwości, że jest ono tożsame ze sformułowaniem „klub parlamentarny”. Podobną interpretację należy zastosować w przypadku art. 143 ust. 1 RSEJ, który określa, że w skład Komisji Etyki Poselskiej wchodzą posłowie, po jednym z każdego klubu poselskiego. Na uwagę zasługuje fakt, że członkami mogą być tylko przedstawiciele klubów. Pozostałym zrzeszeniom to uprawnienie nie przysługuje. W praktyce, liczebność członków poszczególnych klubów w komisjach stałych określana jest na początku każdej kadencji ${ }^{24}$ (począwszy od Sejmu II kadencji, 1993-1997). Skorzystanie więc przez klub z uprawnienia bezpośredniego polega na zgłoszeniu kandydatów w liczbie już wcześniej ustalonej.

Przepisy rozdziału 14 RSEJ odnoszące się do posiedzeń komisji sejmowych wskazują, że prezydium komisji podczas opracowywania projektów planów pracy, czy ustalania porządku dziennego posiedzenia musi wziąć pod uwagę wnioski klubów (obok kół poselskich i poszczególnych posłów) (art. 150 ust. 2). Ponadto za zgodą przewodniczącego danej komisji na jej posiedzeniu mogą być obecni m. in. pracownicy biur klubów poselskich (art. 154 ust. 5). Przepis pomija pracowników biur kół, jednak wydaje się, że na zasadzie wnioskowania per analogiam uzasadnione jest dopuszczanie ich udziału w komisji.

Prawo do składania wniosku o uzupełnienie porządku dziennego na takich samych zasadach mają kluby, koła i grupy co najmniej 15 posłów (art. 173 ust. 3 RSEJ) ${ }^{25}$. Przepis ten jest przykładem na pokrywanie się uprawnień bezpośrednich z pośrednimi.

W trakcie prowadzenia obrad Sejmu klubom parlamentarnym przysługują limity czasowe przemówień posłów w ramach ich wystąpień klubowych. Co do zasady, nie mogą one przekraczać 20 minut, ale Marszałek Sejmu w porozumieniu z Konwentem Seniorów może ustalić inny czas przemówień i przedstawić go do zatwierdzenia Sejmowi (art. 180 ust. 1 RSEJ). Pomija się przedstawicieli - członków kół, wobec których należy stosować uregulowanie zawarte w pierwszej części zdania pierwszego ust. 1 - „Przemówienia posłów w dyskusji nie mogą trwać dłużej niż 10 minut (...)”. Z jednej strony rzec można, że jest to dyskryminacja kół. Z drugiej jednak przyznanie innych limitów mogłoby spowodować nadmierne wydłużanie się obrad, np. poprzez celowe tworzenie kół przez 3 posłów wyłącznie w celu stworzenia uprawnienia do dłuższego przemawiania. Prowadziłoby to raczej do paraliżu niż do usprawnienia pracy izby. W praktyce wykorzystuje się rozwiązania ze zdania drugiego i Sejm zatwierdza inne limity proporcjonalnie do liczby członków zrzeszenia.

\footnotetext{
${ }^{24}$ Por. podział podczas obecnej kadencji Sejmu, http://www.sejm.gov.pl/Sejm8.nsf/page.xsp/parytety, (dostęp: 18.3.2018 r.).

${ }^{25}$ Por. w tym zakresie także uwagi W. Odrowąż-Sypniewskiego, Status prawny wniosków złożonych $w$ trybie art. 173 ust. 3 regulaminu Sejmu przez podmioty, które przestaly istnieć, [w:] Regulamin Sejmu w opiniach Biura Analiz Sejmowych, tom II, red. W. Odrowąż-Sypniewski, Warszawa 2010, s. 404-407.
} 
Wobec dyskusji w postaci debaty w kwestii limitów czasowych stosuje się art. 181 RSEJ. Może być ona prowadzona w formie oświadczeń w imieniu klubów i kół. W tym przypadku kwestia, ilu przedstawicieli wystąpi w ramach przyznanego limitu, leży wyłącznie w gestii klubu lub koła (art. 181 ust. 4 RSEJ) ${ }^{26}$.

Kolejnym uprawnieniem przysługującym tylko klubom i kołom jest fakultatywna możliwość dopuszczenia przez Marszałka Sejmu ich reprezentanta do zadawania pytań przed każdym głosowaniem (art. 182 ust. 2 RSEJ). Niedawna nowelizacja tego przepisu (z 28.2.2018 $\mathrm{r}^{27}$ ) ogranicza uprawnienie klubowe i w pełni uzależnia go od prowadzącego posiedzenie Marszałka ${ }^{28}$. Dokonana tą zmianą realizacja postulatu usprawnienia prac izby oraz ograniczenia obstrukcji parlamentarnej może budzić wątpliwości na tle zasady wolnego mandatu parlamentarnego, z której wynika swobodna możliwość wyrażenia swojego poglądu przez deputowanego podczas prac legislacyjnych (wydaje się również, że taka możliwość powinna istnieć na etapie głosowania). Należy zwrócić uwagę, że i tak została ona w tym przypadku ograniczona poprzez przyznanie jej wyłącznie klubom i kołom, a dokładnie tylko jednemu ich reprezentantowi. Sytuacja, w której owe uprawnienie podlega dalszym ograniczeniom, w tym wprost - w praktyce - uzależnionym od woli przedstawiciela jednej partii ${ }^{29}$, może wpłynąć negatywnie na stopień pluralizmu politycznego i efektywne wykonywanie mandatu.

Klubowi przysługuje również prawo złożenia wniosku o przedstawienie przez członka Rady Ministrów na posiedzeniu Sejmu informacji bieżącej (art. 194 ust. 1 RSEJ). Jeżeli zgłoszonych zostanie kilka propozycji, dokonując wyboru tematu informacji Prezydium kieruje się w głównej mierze jej znaczeniem i aktualnością oraz bierze pod uwagę liczebność klubu. Wyklucza się tutaj również uprawnienie koła. Z uwagi na fakt, że punkt ten odnosi się do bieżących spraw polityki państwa (często tzw. „medialnych”), istotnym przywilejem klubów parlamentarnych jest możliwość zainicjowania włączenia go do porządku dziennego obrad. Może być to rozumiane jako kompetencja kontrolna zrzeszeń wobec działań Rady Ministrów, dokonywana in pleno podczas posiedzenia Sejmu. Ma ona duży wydźwięk

\footnotetext{
${ }^{26}$ Warto zaznaczyć, iż ta kompetencja bezpośrednia przysługuje każdemu klubowi z osobna i w obecnym stanie prawnym nie istnieje możliwość łączenia wystąpienia jednego parlamentarzysty w imieniu więcej niż jednego klubu lub koła (por. J. Mordwiłko, Dopuszczalność wystapień posłów w toku debaty sejmowej w imieniu więcej niż jednego klubu poselskiego lub koła, [w:] Regulamin Sejmu w opiniach Biura Analiz Sejmowych, tom II..., s. 446).

${ }^{27}$ M.P. z 2018 r., poz. 267.

${ }^{28}$ Por. uwagi na tle poprzedniego stanu prawnego, w którym kompetencja Marszałka była ograniczona w odniesieniu do uprawnienia klubów i kół (P. Chybalski, Dopuszczalność zadawania pytań przed glosowaniem przez postów niezrzeszonych, [w:] Ibidem, s. 448.).

29 Pomimo powinności zachowywania bezstronności i obiektywności prowadzącego obrady i głosowania Marszałka Sejmu, która w praktyce nie zawsze jest w pełni zachowywana.
} 
polityczny i wpływa na popularność frakcji, jednak może pociągnąć za sobą inne czynności regulaminowe, np. na skutek wyjaśnionych okoliczności członkowie klubu parlamentarnego składają wniosek o udzielenie wotum nieufności wobec Rady Ministrów.

Uprawnieniem bezpośrednim klubu na gruncie regulaminu Senatu, poza opisywanym wcześniej uczestniczeniem jego przedstawiciela w pracach Konwentu Seniorów, jest wyrażona w art. 84 ust. 6 regulaminu izby wyższej zasada możliwości pominięcia pierwszego czytania projektu uchwały Senatu przy włączaniu go przez Marszałka do projektu porządku obrad danego posiedzenia. Procedura taka może zostać uruchomiona po uzgodnieniu projektu uchwały ze wszystkimi klubami i kołami.

Opisywane uprawnienia mogą również wynikać $\mathrm{z}$ innych aktów prawnych. Przykładem jest kompetencja klubów i kół poselskich oraz parlamentarnych do rozdziału pokoi w Domu Poselskim, wynikająca z § 1 ust. 2 uchwały nr 39 Prezydium Sejmu z 10.12.1997 r. w sprawie zakwaterowania posłów (ze zmianami) ${ }^{30}$, a także klubów i kół senackich na podstawie $\S 1$ ust. 5 uchwały nr 200 Prezydium Senatu z 5.7.2001 r. w sprawie zasad korzystania przez senatorów $\mathrm{z}$ zakwaterowania $\mathrm{w}$ mieście stołecznym Warszawie oraz wysokości środków finansowych przeznaczonych na pokrycie niektórych kosztów działalności senatora ${ }^{31}$. Prima facie wydaje się, że nie mieści się ona w zakresie kompetencji klubów rozumianych w ścisłym znaczeniu, to jest związanych z wykonywaniem mandatu przez parlamentarzystę w procesie stanowienia prawa. Jednakże w myśl art. 46 ust. 1 UWMPS in principio, na podstawie którego wydane zostały przedmiotowe akty wewnętrzne, Prezydium Sejmu i Prezydium Senatu udzielają posłom i senatorom pomocy w wykonywaniu przez nich mandatów. Abstrakcyjnie, na mocy stosownej uchwały, czynności wynikające z pomocniczo przyznanych w niej uprawnień, pozostają w związku z wykonywaniem mandatu. Także konkretna czynność rozdziału pokoi w Domu Poselskim, przyznana określonym zrzeszeniom, winna być rozumiana jako czynność „w związku”, a nie „obok” wykonywania mandatu parlamentarzysty. Zachodzi w tym przypadku faktyczny związek pomiędzy uprawnieniem do rozdziału pokoi i czynnością dokonywaną na jego podstawie, w ramach wykonywania mandatu, a samym procesem stanowienia prawa. W praktyce obecność posła czy senatora na obradach izby, komisji oraz udział w głosowaniach (czyli czynny udział W stanowieniu prawa), jest kluczowym elementem wykonywania jego mandatu, a jednocześnie wiąże się $\mathrm{z}$ fizyczną możliwością przebywania w Warszawie.

\footnotetext{
$30 \quad$ Http://orka.sejm.gov.pl/BOP_info.nsf/0/D225491777059A02C1257990002BF9D7/\%24File/UPS1997039ujed7.pdf, (dostęp: 18.3.2018 r.).

${ }^{31} \mathrm{Https}$ ///www.senat.gov.pl/gfx/senat/userfiles/_public/bss/dokumenty/12_2.doc, (dostęp: 18.3.2018 r.).
} 
Tak wykazany związek pozwala na włączenie tejże kompetencji do uprawnień klubów rozumianych w wąskim znaczeniu w kategorii formalnych uprawnień bezpośrednich ${ }^{32}$.

Konkludując, szereg przepisów regulaminowych nadaje szerokie kompetencje bezpośrednie klubom parlamentarnym, często pomijając inne zrzeszenia. Tym sposobem umacnia się pozycja tego typu zrzeszenia względem kół. Uchwałodawca, co do zasady, stara się wyposażać w tożsame kompetencje wszystkie zrzeszenia, jednak niektóre unormowania jednoznacznie uprzywilejowują frakcje zorganizowane w klub.

\section{Pośrednie uprawnienia klubów parlamentarnych}

Tryb powołania oraz odwołania Marszałka i wicemarszałków Sejmu związany jest z kompetencjami pośrednimi klubów. Kandydaturę na przewodniczącego izby zgłasza co najmniej 15 posłów (art. 4 ust. 2 RSEJ). W drodze uchwały Sejmu ustala się liczbę wicemarszałków. Projekt uchwały w tym przedmiocie, przyjmowanej w jednym czytaniu, może wnieść również co najmniej 15 posłów (art. 5 ust. 2 i 3 RSEJ). W procedurze zgłaszania kandydatów i wyboru wicemarszałków stosuje się odpowiednio przepisy odnoszące się do Marszałka Sejmu.

Wymogom regulaminowym związanym $\mathrm{z}$ rozpoczęciem funkcjonowania izby uchwałodawca nadał formę kompetencji przewidzianych dla określonej liczby posłów popierających wnioski. Gwarantuje to każdemu członkowi izby, bez względu na preferencje polityczne, uzyskanie mandatu z konkretnej listy wyborczej czy poparcie dowolnego wniosku. Na uwagę zasługuje fakt, że rola klubów nie jest tu wyłączona; mają one prawo przedstawić swoich kandydatów, ale i tak formalnie nie będzie to wniosek klubu in pleno - w imieniu zrzeszenia - a dokument podpisany przez określoną liczbę parlamentarzystów z tej samej frakcji parlamentarnej. Niewątpliwie takie procedowanie oddaje sens kompetencji pośrednich klubu. Co więcej, jeśli chodzi o zgłaszanie kandydata na Marszałka Sejmu, każdy poseł może poprzeć tylko jedną kandydaturę (art. 4 ust. 2 RSEJ). Praktyka pokazuje, że decyzja klubu (czy to kolegialna, czy jednoosobowa przewodniczącego klubu, szefa frakcji etc.) choć nieformalnie, to skutecznie wiążąca dla jego członków. Możliwość poparcia jednego kandydata faktycznie umacnia pozycję klubów, co dzieje się także przez łatwość wyłonienia kandydatur (np. przez głosowanie), dyskusji i przeprowadzenia procesu zbierania podpisów. Usus ten charakteryzuje największe kluby parlamentarne.

\footnotetext{
${ }^{32}$ Praktyka pokazuje, że parlamentarzyści uprawnieni do zakwaterowania w Domu Poselskim, korzystają częściej z możliwości wynajęcia mieszkania na czas trwania ich mandatów.
} 
Warto zauważyć, że wymagana liczba podpisów przy składaniu wniosku o odwołanie przewodniczącego izby jest większa, niż przy procedurze zgłaszania kandydata, i wynosi co najmniej 46 (art. 10a ust. 1 RSEJ). Co więcej, wniosek taki musi posiadać cechy konstruktywności. Wraz z żądaniem odwołania Marszałka należy wskazać imiennie nowego kandydata. Głosowanie nad tym wnioskiem w obydwu jego punktach odbywa się łącznie (art. 10a ust. 2 RSEJ). Jest to sytuacja analogiczna do opisanego w art. 158 ust. 1 zdanie pierwsze Konstytucji RP konstruktywnego wotum nieufności wobec Rady Ministrów. Wyższy próg ilościowy ma zapewnić względną nienaruszalność i stabilność funkcji Marszałka, preferując jednak w praktyce tym samym większe zrzeszenia. Rozwiązanie to uzasadniają argumenty analogiczne do tych dotyczących procedury z art. 4 RSEJ. Jeśli chodzi o złożenie wniosku w sprawie odwołania wicemarszałka Sejmu, wymagana jest minimalna liczba 15 podpisów (art. 10a ust. 5 RSEJ). Pokazuje to wiodącą rolą klubów.

W opisanych sytuacjach koła poselskie są zmuszone do „dołączania się” do innych wniosków lub nieuczestniczenia w zgłaszaniu kandydatów. Prawo wpływu każdego posła na wybór i odwołanie Marszałka i wicemarszałków jest zapewnione w głosowaniu podczas posiedzenia Sejmu. Niewątpliwie jednak sam proces zgłaszania kandydatur faworyzuje kluby ${ }^{33}$.

Podobna procedura obowiązuje w Senacie. Gdy rzecz dotyczy wyboru Marszałka i wicemarszałków, kandydaturę może zgłosić co najmniej 10 senatorów (art. 6 ust. 1 i art. 7 ust. 1 RSEN). Wolę odwołania osób pełniących te funkcje musi wskazać w swym wniosku przynajmniej 34 senatorów (art. 6 ust. 3 i art. 7 ust. 2 RSEN).

Kolejnym przykładem na pokrywanie się dwóch rodzajów kompetencji formalnych jest procedura z art. 16 ust. 2 RSEJ, dotycząca wnioskowania o zwołanie Konwentu Seniorów - może to zrobić klub lub grupa co najmniej 15 posłów.

W ramach kompetencji kreacyjnych Sejmu wymagane są zazwyczaj większe liczby podpisów: co najmniej 35 (,wnioski w sprawie wyboru lub powołania przez Sejm poszczególnych osób na stanowiska państwowe określone w art. 26 i 29” i wyboru Rzecznika Praw Dziecka), co najmniej 50 (zgłaszanie kandydata na stanowisko sędziego Trybunału Konstytucyjnego) - art. 30 ust. 1 RSEJ. Taka sytuacja sprzyja najliczniejszym klubom, które dużo łatwiej i szybciej mogą pozyskać podpisy swoich członków.

\footnotetext{
33 Por. druk nr 3, Sejm VIII kadencji, dot. listy kandydatów na wicemarszałków Sejmu RP; http:/orka.sejm.gov.pl/Druki8ka.nsf/0/E34BE0FF4018429EC1257EFB0063EE58/\%24File/3.pdf, (dostęp: 18.03.2018 r.). Poszczególne kandydatury zgłoszone zostały wyłącznie przez posłów przynależących do klubów. Co ciekawe, w druku sejmowym posłużono się pewnym „skrótem myślowym” określając wnioskodawców kandydatur, jako grupy posłów klubów parlamentarnych bądź poselskich.
} 
W Senacie kompetencje kreacyjne parlamentu dotyczące wyboru senatorów do Krajowej Rady Sądownictwa, członka Krajowej Rady Radiofonii i Telewizji, członków Rady Polityki Pieniężnej oraz członków Kolegium Instytutu Pamięci Narodowej - Komisji Ścigania Zbrodni przeciwko Narodowi Polskiemu wykonywane są w trybie zgłaszania kandydatur przez grupę co najmniej 7 senatorów (art. 93 ust. 1 RSEN).

Inicjatywa ustawodawcza przysługuje wyłącznie w ramach kompetencji pośrednich. Regulamin zapewnia m. in. możliwość partycypacji każdego posła w tej inicjatywie, niezależnie od jego preferencji politycznych. Projekt ustawy musi być podpisany przez co najmniej 15 posłów (art. 32 ust. 2 RSEJ). Z inicjatywy uchwałodawczej, co do zasady, również może skorzystać 15 posłów (wyjątek art. 148ca ust. 1 i art. 148cb ust. 1 RSEJ uprawnienie przysługujące wyłącznie Komisji do Spraw Unii Europejskiej). W praktyce kluby często korzystają z tych uprawnień, jednak nadal jest to inicjatywa ustawodawcza posłów, tyle że w takim przypadku, poparta przez członków określonej frakcji ${ }^{34}$. Wniesienie projektu ustawy o zmianie Konstytucji może być dokonane przez co najmniej 1/5 ustawowej liczby posłów (92), zgodnie z art. 235 ust. 1 Konstytucji. Norma ta w praktyce w dużym stopniu faworyzuje największe frakcje ${ }^{35}$.

Na gruncie regulaminu Senatu wniosek o podjęcie przez Senat postępowania w sprawie inicjatywy ustawodawczej może zgłosić co najmniej 10 senatorów (art. 76 ust. 1 RSEN); podobnie jak w Sejmie wykluczona została możliwość działania in pleno klubu w tej kwestii.

Dużym klubom parlamentarnym łatwiej jest wnioskować o poddanie określonej sprawy pod referendum ogólnokrajowe, gdyż taki wniosek składa co najmniej 69 posłów (art. 65 ust. 3 RSEJ).

W toku powoływania Rady Ministrów w tzw. drugiej procedurze (art. 154 ust. 3 Konstytucji) kandydata na Prezesa RM może zgłosić co najmniej 46 posłów (art. 113 ust. 1 RSEJ). Co najmniej 115 posłów może wnioskować o podjęcie uchwały

\footnotetext{
${ }^{34}$ A. Szmyt, Tryb uchwalania ustaw przez Sejm w świetle nowej konstytucji i regulaminu Sejmu, Raport nr 113, „Biuro Studiów i Ekspertyz” 1997, nr X/97, s. 26. „Grupę 15 posłów wyodrębnia Regulamin Sejmu według kryterium liczby podpisów, bez znaczenia prawnego są więc inne cechy, choć w praktyce sejmowej $\mathrm{w}$ szczególności chodzi często o kryterium partyjne. Ponieważ regulaminowa liczebność grupy mogącej utworzyć na zasadzie czysto politycznej - klub (art. 9 ust. 2), jest taka sama, jak grupy uprawnionej do inicjatywy ustawodawczej, to de facto każdy klub poselski może przedłożyć Sejmowi projekt ustawy samodzielnie, niezależnie od poparcia innych sił politycznych w Izbie. Z brzmienia przepisu regulaminowego wynika jednak, że prawnie biorąc to nie klub (frakcja) ma prawo inicjatywy ustawodawczej, a składane przez posłów podpisy świadczyć mają o ich indywidualnym poparciu dla projektu. Wycofanie podpisu przez niektórych posłów powoduje - jeśli oznacza to spadek liczby podpisów poniżej regulaminowej granicy - brak poparcia przez "uprawniony" podmiot, co czyni projekt nieistniejącym prawnie.".

${ }^{35}$ Eliminując także w tym wypadku przewidzianą na gruncie RSEJ inicjatywę ustawodawczą komisji sejmowej, por. M. Safjan, L. Bosek (red.), Konstytucja RP. Tom II. Komentarz, Warszawa 2016, komentarz do art. 235, s. 1648 .
} 
o pociągnięciu członka Rady Ministrów do odpowiedzialności przed Trybunałem Stanu (art. 156 ust 2 Konstytucji). Również minimalnie 46 posłów ma prawo złożyć wniosek o udzielenie wotum nieufności wobec całej Rady Ministrów, zaś 69 wobec konkretnego ministra (art. 158 ust. 1 i art. 159 ust. 1 Konstytucji). Te dwa wnioski ponownie złożone przed upływem 3 miesięcy od poprzednich wymagają podpisów co najmniej 115 posłów (art. 158 ust. 2 i art. 159 ust. 2 Konstytucji). Z wnioskiem do Trybunału Konstytucyjnego w sprawach, o których mowa w art. 188 Konstytucji, może wystąpić m. in. 50 posłów (art. 191 ust. 1 pkt 1 Konstytucji). Jak widać, wiele przepisów Konstytucji odnosi się do wniosków grupy posłów, a określone minimalne progi ilościowe stają się możliwe do osiągnięcia dla większych ugrupowań w parlamencie.

Posłowie (co najmniej 46) mogą również zainicjować procedurę powstania komisji śledczej przez wniesienie projektu uchwały w sprawie jej powołania (art. 136a ust. 1 RSEJ). W stosunku do Komisji do Spraw Służb Specjalnych grupa co najmniej 35 posłów (obok przewodniczącego klubu) może zgłosić kandydatów na jej członków (art. 137 ust. 3 RSEJ). To kolejny przykład na pokrywanie się kompetencji bezpośrednich z pośrednimi, a jednocześnie próba uchwałodawcy wyrównania uprawnień klubów i każdego parlamentarzysty. Przepisy dotyczące Komisji do Spraw Unii Europejskiej zawierają liczne uprawnienia przysługujące co najmniej 15 posłom. Tak jest w przypadku wnoszenia projektu uchwały w sprawie uznania projektu aktu ustawodawczego UE za niezgodny z zasadą pomocniczości (art. 148cc ust. 1 RSEJ), projektu uchwały w sprawie wniesienia do Trybunału Sprawiedliwości UE skargi w sprawie naruszenia przez akt ustawodawczy UE zasady pomocniczości (art. 148cd ust. 1 RSEJ), projektu uchwały w sprawie cofnięcia skargi, o której mowa w art. 148cd ust. 1 (art. 148ce ust. 1 RSEJ), wniosku w sprawie wyboru przedstawicieli do konwentu, o którym mowa w art. 48 ust. 3 Traktatu o Unii Europejskiej (art. 148cf ust. 3 RSEJ). W kwestii opracowywania projektów planów pracy komisji sejmowych, w tym porządków dziennych ich posiedzeń, również bierze się pod uwagę wnioski poszczególnych posłów obok klubów czy kół (art. 150 ust. 2 RSEJ).

Wyróżnione wcześniej dwa rodzaje kompetencji formalnych są tożsame również w przypadku wniosków o uzupełnienie porządku dziennego posiedzenia Sejmu, które mogą także zgłaszać grupy co najmniej 15 posłów (art. 173 ust. 3 RSEJ).

Procedura głosowania imiennego może zostać uruchomiona na wniosek poparty przez minimalnie 30 posłów lub Marszałka Sejmu (art. 188 ust. 4 RSEJ). Wyklucza się tutaj kompetencje bezpośrednie klubów. Podobnie dzieje się w przypadku wniosku w sprawie rozstrzygnięcia o reasumpcji głosowania przez Sejm. Jednak w tym wypadku, zgodnie 
z art. 189 ust. 3 RSEJ, mogą go zgłosić tylko posłowie w tej samej liczbie, jak wymaganej $\mathrm{w}$ procedurze $\mathrm{z}$ art. 188.

Głosowanie imienne lub przez podniesienie ręki w izbie wyższej może zostać zarządzone $m$. in. na wniosek minimum 20 senatorów (art. 53 ust. 3 RSEN). Zgodnie zaś z art. 36 ust. 2 RSEN m. in. na wniosek 10 senatorów Senat może uchwalić odpowiednią większością tajność obrad (po spełnieniu innych przesłanek).

Artykuł 194 RSEJ, dotyczący wniosku o przedstawienie informacji bieżącej, o którym była już mowa przy kompetencjach bezpośrednich, znajduje swe zastosowanie także wobec grupy co najmniej 15 posłów i jest kolejnym przykładem na pokrywanie się tych uprawnień z kompetencjami pośrednimi. W zdaniu trzecim ust. 3 tego artykułu, określającym przesłanki, które bierze się pod uwagę w wyborze zgłoszonych propozycji, brak jest wskazania liczebności grupy posłów, co może sygnalizować jednak praktyczne postrzeganie tego przywileju przez uchwałodawcę, który przewiduje składanie większości takich wniosków przez zrzeszenia i to gwarantuje im pierwszeństwo. Z drugiej strony jest to tylko kryterium pomocnicze wobec aktualności i znaczenia propozycji.

Zmiana RSEJ następuje na wniosek m. in. co najmniej piętnastoosobowej grupy posłów, wykluczając w tej kwestii uprawnienia klubów (zrzeszeń), jako jednego ciała (art. 203 RSEJ).

Podobnie stanowią regulacje dotyczące Senatu, grupa popierających wniosek o zmianę regulaminu tej izby liczyć musi co najmniej 10 senatorów (art. 101 RSEN).

\section{Podsumowanie}

Przedstawiony zakres uprawnień klubów parlamentarnych świadczy o ich ważnej pozycji w strukturze polskiego parlamentu. Wiele unormowań Regulaminu Sejmu RP wyraźnie wskazuje na uprzywilejowany status klubów wobec kół czy grup posłów. W praktyce, to działalność klubów determinuje procedowanie obu izb. Największe frakcje w Sejmie i Senacie RP, zakładając kluby parlamentarne, realnie sterują pracami parlamentu, W szczególności wnosząc nowe projekty ustaw oraz podejmując wiążące decyzje w głosowaniach na poziomie komisji i posiedzenia plenarnego. Dzięki licznym kompetencjom zrzeszeń dochodzi do urzeczywistnienia zasady pluralizmu politycznego i wolnego mandatu parlamentarnego. Postępowanie przez posłów i senatorów zgodnie z zakreślonymi przez regulaminy izb wytycznymi koreluje z art. 2 Konstytucji RP (poprzez reglamentację prawną pracy parlamentu właśnie w formie regulaminu). Regulaminowe zagwarantowanie standardów pluralizmu sprzyja więc efektywnemu urzeczywistnianiu zasady demokratycznego państwa 
prawnego. Pomimo niezaliczenia regulaminów do aktów powszechnie obowiązujących, stanowią one specyficzny rodzaj, ,aktu samoistnego, wydawanego wprost w oparciu o Konstytucję (...)"36, które regulując kwestie wewnętrznej organizacji izb, są aktem wykonawczym do Konstytucji ${ }^{37}$. Ów „konstytucyjny rodowód” regulaminów obu izb nadaje im szczególne znaczenie, podkreślając także rolę zrzeszeń parlamentarnych, w tym zwłaszcza klubów parlamentarnych.

Polski uchwałodawca określa kompetencje zrzeszeń parlamentarnych oraz grup posłów w skomplikowany sposób. Często decyduje się na przyznanie ich klubowi z pominięciem kół czy grup parlamentarzystów lub na odwrót. Taki zabieg sprawia wrażenie braku dostatecznego uporządkowania poszczególnych przepisów i trudno jest w nim dostrzec racjonalne uzasadnienie.

Warto w tym miejscu zwrócić uwagę na uregulowania obowiązujące w parlamencie Republiki Federalnej Niemiec, a dokładnie w jednej z jego izb - Bundestagu (w Bundesracie, z uwagi na specyficzny charakter tej izby $^{38}$ regulamin nie wprowadza uprawnienia do zrzeszania się poszczególnych deputowanych) ${ }^{39}$, które również przyznają szerokie kompetencje zrzeszeniom (szczególnie klubom) oraz grupom deputowanych w sposób zdecydowanie bardziej konsekwentny (najczęściej łącznie klubom i grupom, co pozwala zachować spójne nazewnictwo i logiczny tryb procedowania) $)^{40}$.

\footnotetext{
${ }^{36}$ Orzeczenie Trybunału Konstytucyjnego z 26.1.1993 r., U 10/92, OTK 1993, nr 1, poz. 2.

${ }^{37} \mathrm{O}$ dużej swobodzie w kształtowaniu zakresu przedmiotowego tego aktu, przybierającego formę uchwały, a nie ustawy, która to jest wyrazem zasady autonomii regulaminowej parlamentu por. M. Safjan, L. Bosek (red.), op. cit., komentarz do art. 112, s. 405; wyrok Trybunału Konstytucyjnego z 14.4.1999 r., K 8/99, OTK 1999, nr 3, poz. 41.

${ }^{38}$ Członkowie Bundesratu - reprezentanci poszczególnych landów w organie federalnym - są jednocześnie członkami organów władzy regionalnej, tj. niemieckich krajów związkowych, posiadają mandat związany oraz głosują wyłączne en bloc. Por. P. Czarny, Bundesrat : między niemiecka tradycja a europejska przyszłościa, Warszawa 2000; K. Kociubiński, Systemy polityczne Austrii, Niemiec i Szwajcarii, Wrocław 2003, S. Sulowski, System polityczny Republiki Federalnej Niemiec (wybrane problemy), Warszawa 2005; G. Ziller, Der Bundesrat, Düsseldorf 1998.

39 Zob. Rules of Procedure of the German Bundestag and Rules of Procedure of the Mediation Committee, Deutscher Bundestag, Berlin 2014, https://www.btg-bestellservice.de/pdf/80060000.pdf, (18.03.2018 r.); Rules of Procedure of the Bundesrat, https://www.bundesrat.de/EN/funktionen-en/go-en/go-ennode.html\#doc5157334bodyText1, (dostęp: 18.3.2018 r.).

${ }^{40}$ Deputowani do niemieckiej izby niższej zgodnie z zasadą wyrażoną w art. 10 ust. $1-5$ jej regulaminu mogą tworzyć określone zrzeszenia. Podstawowe, jakim jest klub parlamentarny, tworzy minimum $5 \%$ liczby członków Bundestagu, należących do tej samej bądź różnych partii o podobnych poglądach i bezkonfliktowych relacjach w każdym z landów. Nieosiągnięcie tego progu ilościowego pozwala deputowanym na utworzenia koła. Przykładami uregulowań, w których konsekwentnie przyznaje się kompetencje klubom i grupie minimalnie 5\% członków izby są: art. 20 ust. 3 - wniosek uzupełnienie porządku dziennego; art. 25, 26 - wniosek o zawieszenie lub zakończenie debaty albo o zawieszenie posiedzenia plenarnego; art. 42 wniosek w sprawie wezwania w celu wysłuchania m. in. członka rządu federalnego; art. 45 ust. 2 - zarzut braku quorum; art. 52 - wniosek o przeprowadzenie głosowania imiennego; art. 78- 86 - uprawnienia związane z procesem trzech czytań projektu ustawy, np. wniosek o debatę na posiedzeniu plenarnym; art. 93b - uprawnienia związane z pracami w komisji do spraw Unii Europejskiej; art. 127 ust. 1 - wniosek o interpretację przepisów regulaminu przez powołane do tego organy.
} 
Zwraca uwagę odmienny od polskiego sposób legislacji, w szczególności formułowanie zakresu podmiotowego, a nie zakresu i typu przyznanych uprawnień. Technika legislacyjna niemieckich przepisów sprzyja koherentności całej regulacji i, zdaniem Autora, może być wzorcem dla przyszłych zmian regulaminu Sejmu i Senatu. De lege ferenda należałoby także doprecyzować przepisy regulaminowe Sejmu w zakresie używanych pojęć: „klub”, „klub poselski”, „klub parlamentarny”. Zastosowane rozróżnienie powinno być przez ustawodawcę konsekwentnie przestrzegane. Dotychczasowy brak konsekwencji w tym względzie, zamienne używanie pojęć, czyni analizowaną regulację niezrozumiałą, nieuporządkowaną logicznie, przez co zmusza doktrynę do ujednolicania tych pojęć, w szczególności w odniesieniu do uprawnień klubów parlamentarnych.

\section{Summary \\ Selected formal, legal and practical aspects of parliamentary clubs' competences \\ Author presents selected formal, legal and practical aspects of parliamentary clubs' competences. The article contains general informations about them. The article is based on a legal explanation and interpretation of, mainly, the Standing Orders of the Sejm of Republic of Poland, the Rules and Regulations of the Senate of Republic of Poland and other statues. The paper contains main views of the doctrine and jurisdiction referring to the topic of the article. What is more, author describes a phenomenon of parliamentary discipline - a duty of an every member of parliamentarians' associations. The second part of the publication contains short description of parliamentary clubs' competences in the Bundestag.}

\section{Bartlomiej Ślemp}

Student IV roku prawa na Wydziale Prawa i Administracji Uniwersytetu Warszawskiego. 